\title{
Sprawozdanie z wyjazdów do Biblioteki Polskiej w Paryżu 17-21 maja 2016 r. i 5 września - 28 października 2016 r.
}

Pierwszy mój wyjazd do Paryża w maju 2016 r. związany był z przygotowaniem wystawy kartograficznej. W ramach obchodów Międzynarodowego Roku Mapy, Stacja Naukowa PAN przy współudziale szeregu instytucji zorganizowała w Paryżu w dniach 1-4 czerwca 2016 r. Polsko-Francuski Kongres Geograficzny („Assises franco-polonaises de Géographie”), w ramach którego Biblioteka Polska w Paryżu we współpracy z Archiwum Narodowym w Krakowie przygotowała wystawę map z kolekcji Polskiego Towarzystwa Historyczno-Literackiego/Biblioteki Polskiej „LES VOYAGES À TRAVERS L'HISTOIRE 2e Partie” („Podróże przez historię część 2”) - komisarze wystawy Anna Czarnocka - Biblioteka Polska w Paryżu, Zbigniew Dyrdoń - Archiwum Narodowe w Krakowie.

W 2014 r. miała miejsce pierwsza wystawa „Podróż przez historię. Zbiór Kartograficzny SHLP/BPP”. Pokazano na niej najcenniejsze i najciekawsze mapy, plany oraz widoki miast z okresu XV-XVIII w. Obecnie zaprezentowano obiekty unaoczniające wzajemne powiązania Polski i Francji. Główny nacisk położono na uczonych i kartografów działających na emigracji we Francji po powstaniu listopadowym. Wystawione zostały mapy wykonane m.in. przez Joachima Lelewela, Ignacego Domeykę, Leonarda Chodźkę, Józefa Bema, Jędrzeja Sławaczyńskiego, Feliksa Wrotnowskiego.

Nie mogło zabraknąć sztandarowego osiąnięcia polskich emigrantów na polu kartografii tzw. mapy Chrzanowskiego „Karta dawnej Polski według nowszych materyałów na 1:300 000”. Opracowania tej mapy podjął się ok. 1840 r. zespół kartografów z dawnego Kwatermistrzostwa Wojska Polskiego, pod kierownictwem gen. Wojciecha Chrzanowskiego, inicjatora tej pracy, a następnie Feliksa Wrotnowskiego. Mapa Chrzanowskiego jest jedyną mapą topograficzną Polski w granicach historycznych opracowaną przez Polaków podczas zaborów. Została wydana sumptem Biblioteki Polskiej.

Innym ciekawym zabytkiem kartografii z tego okresu pokazanym na wystawie były odbitki fotograficzne w skali 1:1 „Topograficznej Karty Królestwa Polskiego” oraz „Vojenno-topograficzeskoj Karty Rossii”, obejmującej teren Wielkiego Księstwa Litewskiego. Odbitki sporządzono w Paryżu dla potrzeb powstańców styczniowych, staraniem Ksawerego Branickiego. Zdecydowano się na tę odważną i pionierską decyzję użycia fotografii do powielenia tych map, ponieważ jak pisał książę Władysław Czartoryski: „Był to najprędszy, najtańszy i jedynie możebny sposób reprodukcji”. Są to pierwsze przykłady zastosowania fotografii do reprodukcji kartograficznej dla potrzeb polskich i jedne z pierwszych na świecie.

Druga część wystawy poświęcona była mapom ziem polskich autorstwa kartografów francuskich, takich jak Piotr Duval, Mikołaj Sanson, Wilhelm le Vasseur de Beauplan z XVII w., Wilhelm Delisle, Mikołaj de Fer, Karol de Perthées z XVIII w. oraz J. Andri- 
veau-Goujon, J. M. B. Chamouin, Adolf Hipolit Dufour we współpracy z Feliksem Wrotnowskim, Piotr Tardieu, Ludwik Vivien de Saint Martin z XIX w.

Uroczyste otwarcie wystawy przez prezesa Towarzystwa Historyczno-Literackiego i dyrektora Biblioteki Polskiej p. prof. Kazimierza Piotra Zaleskiego miało miejsce 20 maja. Tylko w trakcie „Nocy Muzeów”, 21 maja, wystawę map oraz inne ekspozycje (Muzeum A. Mickiewicza, Salon Chopina, Muzeum Biegasa) zwiedziło ponad 150 osób. Wzbudziła również wielkie uznanie wśród uczestników Kongresu. Można ją było oglądać w Bibliotece Polskiej w Paryżu do 17 czerwca. W tym czasie odwiedziło ją ponad 400 osób.

Drugi jesienny wyjazd był moim szóstym z kolei (poprzednie w latach 2008-2013 i 2015) w ramach programu Ministra Kultury i Dziedzictwa Narodowego „Dziedzictwo Kulturowe”, priorytet „Ochrona dziedzictwa kulturowego za granicą”, zadanie „Porządkowanie zbiorów archiwalnych za granicą".

Podczas tego pobytu kontynuowałem prace nad druga serią map: „Mapy XIX w.” licząca ponad tysiąc jednostek. Zinwentaryzowałem w pliku Excel 261 map (sygnatury II T 1 - II Z 24, II WrF 1 - 16 - mapy Wrotnowskiego, II ChW 1 - 6 - mapy W. Chrzanowskiego oraz II 1 - 135). Część map wyłączono do atlasów (nowe sygnatury zostaną nadane po uporządkowaniu atlasów). Opracowanie map wymagało żmudnej kwerendy naukowej (np. ustalenie autora, daty wydania, dzieła, w którym mapa była zamieszczona), co zajęło dużo czasu. Obecnie zinwentaryzowanych jest 1820 obiektów (w tym 887 XIX-wiecznych). Do opracowania pozostały 84 mapy (sygn. II 136 - 219), 44 plany miast, ok. 30 planów bitew, kilkanaście map ściennych, mapy niezinwentaryzowane oraz po dezynfekcji (nieokreślona ilość) i ok. 120 atlasów.

W trakcie tego pobytu wziąłem udział w transporcie materiałów do dezynfekcji we Francuskiej Bibliotece Narodowej. W czasie mojej bytności w Bibliotece Polskiej odbywały się liczne imprezy kulturalne i naukowe. Można było obejrzeć wystawy: „Le sculpteur François Black (1881-1859). L'art sobre, précis et humain” (Franciszek Black, ur. 1881 w Warszawie, zm. 1959 w Paryżu, rzeźbiarz działający w ciąu całego okresu aktywności twórczej w Paryżu i w Szwajcarii. Razem z Antonim Wiwulskim uczestniczył w realizacji Pomnika Grunwaldzkiego) oraz „VAN HAARDT (1907-1980). Une vie - deux biographies" (Kazimierz Jerzy Brodnicki ur. 1907 w Poznaniu, zm. 1980 w Paryżu). Ponadto była okazja do wysłuchania wykładu arcybiskupa łódzkiego, a obecnie metropolity krakowskiego ks. Marka Jędraszewskiego „1050 Anniversaire du baptême de la Pologne”, licznych koncertów muzycznych, a także wzięcia udziału w konferencjach naukowych: „Paris Cracovie, objectif commun” (,Paryż - Kraków - wspólny cel”) zorganizowanej przez PAU i Towarzystwo Historyczno-Literackie, „Les mouvements non-violents en Pologne (19451990). Une perspective franco-polonaise" (Towarzystwo Historyczno-Literackie i Instytut Pamięci Narodowej). 